\title{
Seasonal and annual abundance of Ephuta wasp (Hymenoptera: Mutillidae) in Panama
}

\author{
Yostin J. Añino ${ }^{1}$, Roberto A. Cambra ${ }^{1}$, Donald M. Windsor ${ }^{2}$, Kevin A. Williams ${ }^{3}$, \\ Pedro R. Bartholomay ${ }^{4}$, Vanessa Sánchez ${ }^{5} \&$ Diomedes Quintero ${ }^{1}$ \\ 1. Museo de Invertebrados G. B. Fairchild, Universidad de Panamá, Panamá 0824, Panamá; yostin0660@gmail.com, \\ cambramiup60@gmail.com,dquinter666@gmail.com \\ 2. Smithsonian Tropical Research Institute, Balboa, Ancón, Panamá; windsordm@gmail.com \\ 3. Plant Pest Diagnostics Center, California Department of Food and Agriculture, Sacramento, California, USA; \\ kevin.williams@cdfa.ca.gov \\ 4. Instituto Nacional del Bosque Atlántico (INMA), Av. José Ruschi, número 4, CEP: 29650-000, Santa Teresa, Espírito \\ Santo, Brasil; pedroreck@gmail.com \\ 5. Instituto Conmemorativo Gorgas de Estudios de la Salud, Panamá, Panamá; vsanchez@gorgas.gob.pa
}

Received 04-IX-2019. Corrected 22-I-2020. $\quad$ Accepted 17-III-2020.

\begin{abstract}
Introduction: Ephuta Say is a widespread New World genus of mutillid wasp whose ecology is poorly understood. Objective: The objective of this study was to determine how Ephuta species abundance varies annually and seasonally driven by weather conditions and hosts. Methods: Ephuta specimens, located in the "old forest" at Barro Colorado Island, were examined from weekly samples (2001-2006) of ten Malaise traps. The monthly abundance of each Ephuta species was compared with monthly average humidity, solar radiation, temperature and rainfall. Results: Nine species and ten morphospecies were identified. Most specimens were collected from March to June. April was the month reported with the greatest abundance. Of the four abiotic variables measured, only average monthly temperature was correlated with Ephuta abundance. Months with the highest number of Ephuta specimens were correlated with suspected host abundance, as indicated by the monthly abundance of Pompilidae (Hymenoptera) captured during the year 2007. Conclusions: We concluded that Ephuta display strong seasonal variation in abundance, with the peaks occurring during the end of the dry season and beginning of the rainy season, which correlate broadly with temperature and the abundance of their pompilid hosts.
\end{abstract}

Key words: Mutillinae, Pompilidae, ecology, Barro Colorado Island, neotropic.

Añino, Y.J., Cambra, R.A., Windsor, D.M., Williams, K.A., Bartholomay, P.R., Sánchez, V., \& Quintero, D. (2020). Seasonal and annual abundance of Ephuta wasp (Hymenoptera: Mutillidae) in Panama. Revista de Biología Tropical, 68(2), 573-579.

Ephuta Say, 1836 (Mutillidae: Mutillinae) belongs to the subtribe Ephutina of the tribe Mutillini (Brothers \& Lelej, 2017). This widespread New World genus has 236 species, which belong to four valid subgenera (Pagliano et al., 2020). The genus includes many new undescribed morphospecies. There are 13 described species in the subgenera Ephuta Say, 1836 and Ephutopsis Ashmead, 1904 in Panama. Additionally, there is one undescribed morphospecies recorded in the subgenus Ephuseabra Casal, 1968 (Quintero \& Cambra, 1996).

Little information is known about the biology of Ephuta. Cambra, Tunes Buschini, Quintero, Brozoski, and Rudiak Lustosa (2017) listed the known hosts for eight species of Ephuta; each recorded host belonged to the wasp family Pompilidae. Additionally, Aranda and Graciolli (2016) studied the abundance 
of Mutillidae, including Ephuta, and their potential hosts in the Cerrado biome, Mato Grosso do Sul, Brazil. Mutillid seasonality and abundance data have also been published using malaise trap samples in the Nearctic (Deyrup \& Manley, 1990) and Neotropical regions (Cambra, Quintero, Waldren, Bartholomay, \& Williams, 2018; Cambra et al., 2018a). Given the lack of information on this topic, we aim to produce new information on the ecology of Ephuta by comparing their relative abundance with parameters like humidity, solar radiation, temperature, rainfall and host abundance.

\section{MATERIALS AND METHODS}

Study site: The study site was the field station of the Smithsonian Tropical Research Institute (STRI) in Barro Colorado Island (BCI), located in Gatun Lake, Panama Canal, $\left(9^{\circ} 09^{\prime} 17^{\prime \prime} \mathrm{N} \& 79^{\circ} 50^{\prime} 53^{\prime \prime} \mathrm{W}\right)$. The island has a territorial expanse of $54 \mathrm{~km}^{2}$, an elevation approximately $137 \mathrm{~m}$ above sea level and is covered by lowland tropical forest (Cambra et al., 2018a). The climate is humid and warm, with an annual rainfall of $2600 \mathrm{~mm}$ and average temperatures ranging from 25 to $30{ }^{\circ} \mathrm{C}$ (Corro, 2014).

Sampling: Mutillid and pompilid specimens were retrieved from the weekly samples of 10 Malaise traps (Townes, 1972). These were located along the western boundary of the 50-hectare "old forest" (> 400 years old) permanent plot on the central plateau of BCI and were placed at approximately $100 \mathrm{~m}$ intervals. Mutillidae specimens were sampled for six continuous years (2001-2006), while Pompilidae specimens were only sampled during 2007 . The mutillid specimens were identified to species (using the study of the types), or recognized as undescribed morphospecies, by Roberto Cambra. All material examined in this study is deposited in the Museo de Invertebrados G. B. Fairchild, University of Panama (MIUP).

Environmental variables: We used meteorological data recorded annually for BCI through the bioinformatics website of the Tropical Research Institute Smithsonian (http:// biogeodb.Stri.si.edu/physical_monitoring/) and from Windsor (1990). The parameters compared were the monthly averages of humidity $(\%)$, solar radiation $\left(\mathrm{MJ} / \mathrm{m}^{2} /\right.$ day $)$, temperature $\left({ }^{\circ} \mathrm{C}\right)$ and rainfall $(\mathrm{mm})$.

Data processing and analyses: Collection data (trap, month and year) for all specimens were recorded in Excel spreadsheets. A Kruskall-Wallis analysis was used to test for differences in monthly abundance. The seasonality of species abundance was tested with circular statistics by the Rayleigh test of uniformity. Shannon (H) and Simpson (1-D) diversity indices, Equitability (J), and Dominance (D) were calculated by month and sampling years. All environmental parameters were correlated with the abundance of individuals using Spearman's rank-order correlation. Finally, graphs of host (Pompilidae) abundance were constructed from data generated by Corro (2014). All statistical analyses were performed using the programs Oriana 4 (Kovach, 2011), Past 3 and R (R Core Team, 2015).

\section{RESULTS}

\section{Composition of the Ephuta community:} Nine species (males) plus ten morphospecies (six males, four females) of Ephuta were recovered from the examined samples. During the sampling period (2001-2006), species richness remained at 17 species, except for 2001 (16) and 2006 (13) (Table 1). Species that were not collected in certain years had overall lower frequencies with fewer than ten individuals in total, those being: E. abadia (Cresson, 1902) (6), E. singularis (Spinola, 1841) (4) and four morphospecies (3-10 individuals). A significant difference in species richness was observed between sampling months $(\mathrm{P}<0.05)$, varying from nine to 18 species. The months from January to May had the greatest species richness (14-18), while July to December (9-13) had the lowest (Table 2). We found evidence of seasonal in the distribution of species abundance 
TABLE 1

Number of Ephuta specimens captured per year in Barro Colorado Island

\begin{tabular}{|c|c|c|c|c|c|c|c|}
\hline Species & 2001 & 2002 & 2003 & 2004 & 2005 & 2006 & TOTAL \\
\hline Ephuta (Ephuta) abadia (Cresson) & 1 & 0 & 3 & 1 & 1 & 0 & 6 \\
\hline Ephuta (Ephuta) bugabensis (Cameron) & 5 & 12 & 20 & 11 & 8 & 3 & 59 \\
\hline Ephuta (Ephuta) nr. bugabensis (Cameron) & 2 & 16 & 15 & 7 & 11 & 8 & 59 \\
\hline Ephuta (Ephuta) carinata Schuster & 6 & 3 & 6 & 8 & 1 & 4 & 28 \\
\hline Ephuta (Ephutopsis) championi (Cameron) & 1 & 2 & 5 & 8 & 3 & 3 & 22 \\
\hline Ephuta (Ephuta) flavidens Mickel & 17 & 24 & 11 & 8 & 6 & 6 & 72 \\
\hline Ephuta (Ephuseabra) nr. morra Casal & 9 & 14 & 14 & 26 & 13 & 7 & 83 \\
\hline Ephuta (Ephuta) panama Schuster & 11 & 27 & 37 & 23 & 3 & 7 & 108 \\
\hline Ephuta (Ephutopsis) singularis (Spinola) & 0 & 0 & 0 & 1 & 3 & 0 & 4 \\
\hline Ephuta (Ephutopsis) triangularis (Cameron) & 34 & 66 & 90 & 77 & 30 & 47 & 344 \\
\hline Ephuta (Ephuta) trifida (Gerstaecker) & 4 & 15 & 1 & 4 & 12 & 11 & 47 \\
\hline Ephuta sp. 1 & 13 & 18 & 19 & 14 & 10 & 6 & 80 \\
\hline Ephuta sp. 2 & 20 & 15 & 25 & 23 & 2 & 8 & 93 \\
\hline Ephuta sp. 3 & 11 & 18 & 7 & 6 & 5 & 7 & 54 \\
\hline Ephuta sp. 4 & 6 & 18 & 21 & 6 & 12 & 4 & 67 \\
\hline Ephuta sp. 5 & 1 & 2 & 4 & 2 & 1 & 0 & 10 \\
\hline Ephuta sp. 6 & 0 & 1 & 2 & 0 & 0 & 0 & 3 \\
\hline Ephuta sp. 7 & 2 & 1 & 0 & 0 & 1 & 0 & 4 \\
\hline Ephuta sp. 8 & 0 & 1 & 1 & 1 & 0 & 0 & 3 \\
\hline TOTAL & 143 & 253 & 281 & 226 & 122 & 121 & 1146 \\
\hline
\end{tabular}

TABLE 2

Number of Ephuta specimens captured per month in a six year period (2001-2006) from Barro Colorado Island

\begin{tabular}{|c|c|c|c|c|c|c|c|c|c|c|c|c|}
\hline Species & Jan & Feb & Mar & Apr & May & Jun & Jul & Aug & Sep & Oct & Nov & Dec \\
\hline Ephuta abadia (Cresson) & 0 & 1 & 1 & 2 & 1 & 0 & 0 & 1 & 0 & 0 & 0 & 0 \\
\hline Ephuta bugabensis (Cameron) & 0 & 3 & 11 & 19 & 14 & 4 & 1 & 4 & 0 & 0 & 0 & 3 \\
\hline Ephuta nr. bugabensis (Cameron) & 6 & 6 & 3 & 10 & 12 & 7 & 3 & 2 & 4 & 1 & 1 & 4 \\
\hline Ephuta carinata Schuster & 0 & 4 & 5 & 12 & 7 & 0 & 0 & 0 & 0 & 0 & 0 & 0 \\
\hline Ephuta championi (Cameron) & 3 & 0 & 2 & 4 & 3 & 0 & 2 & 0 & 1 & 3 & 0 & 4 \\
\hline Ephuta flavidens Mickel & 3 & 7 & 4 & 14 & 9 & 11 & 7 & 5 & 1 & 4 & 5 & 2 \\
\hline Ephuta nr. morra Casal & 3 & 3 & 7 & 18 & 25 & 8 & 5 & 0 & 4 & 3 & 2 & 5 \\
\hline Ephuta panama Schuster & 3 & 6 & 9 & 36 & 37 & 13 & 0 & 0 & 1 & 0 & 2 & 1 \\
\hline Ephuta singularis (Spinola) & 0 & 0 & 1 & 0 & 1 & 2 & 0 & 0 & 0 & 0 & 0 & 0 \\
\hline Ephuta triangularis (Cameron) & 13 & 16 & 30 & 89 & 83 & 40 & 17 & 11 & 12 & 14 & 5 & 14 \\
\hline Ephuta trifida (Gerstaecker) & 5 & 6 & 1 & 2 & 5 & 9 & 1 & 5 & 5 & 2 & 4 & 2 \\
\hline Ephuta sp. 1 & 1 & 7 & 7 & 13 & 14 & 11 & 5 & 1 & 12 & 6 & 1 & 2 \\
\hline Ephuta sp. 2 & 7 & 9 & 8 & 23 & 8 & 8 & 5 & 4 & 5 & 6 & 7 & 3 \\
\hline Ephuta sp. 3 & 5 & 3 & 2 & 11 & 11 & 12 & 2 & 0 & 2 & 1 & 2 & 3 \\
\hline Ephuta sp. 4 & 3 & 1 & 7 & 12 & 12 & 9 & 10 & 3 & 5 & 2 & 1 & 2 \\
\hline Ephuta sp. 5 & 1 & 1 & 3 & 4 & 0 & 0 & 0 & 0 & 0 & 1 & 0 & 0 \\
\hline Ephuta sp. 6 & 1 & 0 & 0 & 0 & 0 & 1 & 0 & 0 & 1 & 0 & 0 & 0 \\
\hline Ephuta sp. 7 & 0 & 1 & 2 & 0 & 1 & 0 & 0 & 0 & 0 & 0 & 0 & 0 \\
\hline Ephuta sp. 8 & 1 & 1 & 1 & 0 & 0 & 0 & 0 & 0 & 0 & 0 & 0 & 0 \\
\hline TOTAL & 55 & 75 & 104 & 269 & 243 & 135 & 58 & 36 & 53 & 43 & 30 & 45 \\
\hline
\end{tabular}


$(\mathrm{R}=0.472, \mathrm{Z}=255.3, \mathrm{P}<0.001)$ with April being the month of highest number of species.

A total of 1146 specimens (1119 males and 27 females) of Ephuta were collected over six years. 2003 had the highest yearly abundance, with 281 specimens $(24.5 \%)$. The lowest number of individuals were collected in 2005 and 2006 with 122 and 121 specimens respectively (Fig. 1A). The months with the greatest abundance were April (269 specimens) and May (243 specimens), comprising 44.7 $\%$ of all individuals in total. More than 100 individuals were collected in both March and June, with the remaining months contributing fewer than 75 specimens each (Fig. 1B). The most abundant species were E. triangularis (Cameron) (344 specimens or $30.0 \%$ ) and E. panama Schuster (108 or $9.4 \%$ ). Ephuta triangularis was the most abundant species across all the years of this study, as well as in each of the sampling months. The monthly diversity indices were similar: 1-D (0.8307$0.8949)$ and $\mathrm{H}(2.055-2.463)$; as well as the dominance and equitability: D (0.1051-0.1693) and $\mathrm{J}(0.7906-0.9065)$.

Seasonal variation in the abundance of Ephuta, its relationship with abiotic factors and the presence of hosts: Species abundance did not vary significantly with monthly
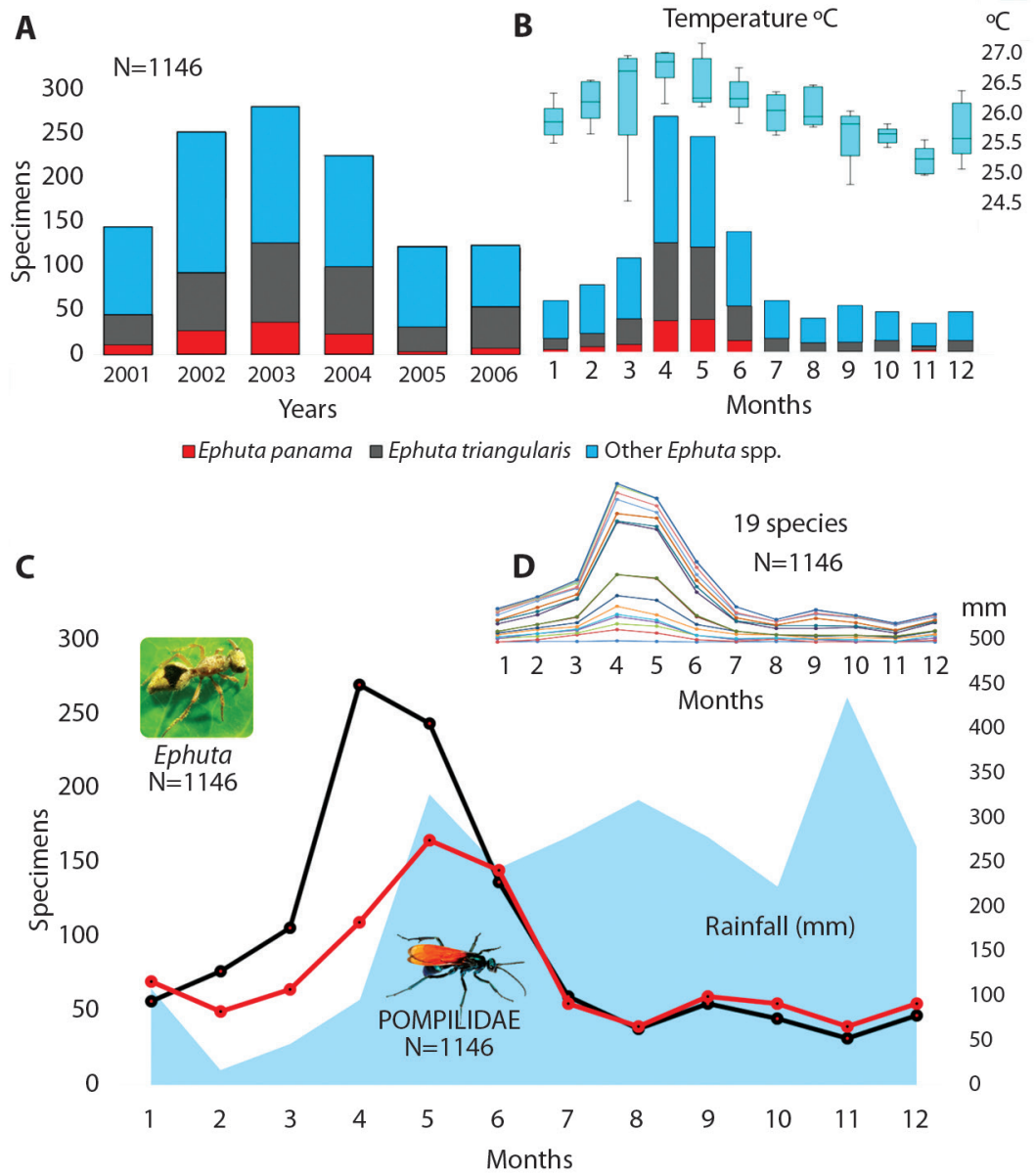

Fig. 1. A. Total Ephuta specimens captured by year (2001-2006). B. Total Ephuta specimens captured by month (20012006) and average monthly temperature. C. Monthly variation of abundance for Ephuta (2001-2006) (black line) and Pompilidae (2007) (red line) with average monthly rainfall (2001-2006) (blue area). D. Monthly variation of Ephuta species (2001-2006). 
average humidity, solar radiation or rainfall ( $\mathrm{P}$ $>0.05)$. There was, however, a positive relationship between average monthly temperature and the number of individuals collected $(\mathrm{P}<$ 0.05 ) in all species combined. Abundance was greatest in months with the highest average temperature $\left(26^{\circ} \mathrm{C}\right)$ (February, March, April, May and June) (Fig. 1B). Although average monthly rainfall did not correlate with Ephuta abundance, the highest abundances occurred in months recording less than $150 \mathrm{~mm}$ of rainfall. Monthly variation in Ephuta abundance throughout the study was similar to that observed in their putative Pompilidae hosts for the year 2007. The months of April, May and June stand out as the most abundant for both wasp families (Fig. 1C). Each of the 19 species of Ephuta studied have different abundances, but they present the same general pattern of abundance per sampling month (Fig. 1D). This last figure (Fig. 1D) shows that the seasonal occurrence of each Ephuta species follows a similar pattern of abundance and richness throughout the months of collection. In certain months, some species cannot be visualized in the graph because some species do not appear in certain months, some lines overlap and four species have consistently low abundance.

\section{DISCUSSION}

The March to June period of high Ephuta abundance coincided with the greatest species richness, which indicates the existence of a shared pattern of seasonality in all Ephuta species on BCI. This was especially pronounced in the most abundant species (Fig. 1B). Diversity indices suggest low differences between the species, with each displaying low dominance and homogeneous equitability. The similar effect of seasonal pattern on species richness and abundance suggests that these indices vary equitably among all Ephuta species on the study site.

The seasonal activity pattern of Ephuta resembles that of other Mutillidae, especially Dasymutilla Ashmead, which has a similar pattern over the same years of collection on
BCI (Cambra et al., 2018a). Additionally, the seasonal activity of Pompilidae species on BCI (Corro, 2014) coincides closely with that found in Ephuta species, possibly reflecting the ecological link between putative host and parasitoid (Aranda \& Graciolli, 2016; Cambra et al., 2017). It should be noted that in a single year of Pompilidae sampling, 910 specimens were collected. On the other hand, for Ephuta, the maximum collected was 281 , a proportion largen than 3.2:1 for the ratio of Pompilidae to Ephuta specimens. Unfortunately, we do not have comparative data on specimens of Pompilidae and Ephuta from the same year. However, the collection methodology and locations are identical.

The synchrony visualized between Pompilidae-Ephuta (Fig. 1C) has been corroborated using a correlation analysis. Without taking into account that our correlation provided with high statistical significance, we do not include it here because the Ephuta data were collected from 5 different years than the Pompilidae records. Since there is not a valid comparison available, presenting a correlation analysis with statistical significance would be misleading. Our sole goal with this data was to visualize their relationship as a preliminary hypothesis that would be worth analyzing at a later date with additional data.

Similar to the results of Corro (2014) for Pompilidae, we found that Ephuta abundance was significantly correlated with average monthly temperature. The latter had no apparent relation with average monthly rainfall, and no significant correlation was observed between average monthly rainfall and average monthly temperature over the six years of our study. When these last two factors were correlated over a longer period (1987-2007), however, a significant negative relationship was observed between average monthly rainfall and temperature. This suggests that rainfall may lower temperatures and thus indirectly plays a role in the seasonal activity of these wasps. When calculating the average monthly rainfall over 20 years (1987-2007), the dry season in BCI presents an average monthly rainfall 
of $200 \mathrm{~mm}$. This could explain why, in this study, no relationship was observed between the average monthly rainfall and Ephuta abundance since the monthly rainfall average in the whole study period (2001-2006) was $200 \mathrm{~mm}$, except for November.

Wolda (1988) argued there existed a variety of seasonal patterns in insect species of tropical forests and thought that these patterns were primarily related to temperature. Our results support this hypothesis, since greater abundance of Ephuta occurs when temperatures are higher than normal, and conversely, lower abundances occur when temperatures are lower than normal. Wolda (1989) also mentioned that activity peaks in seasonal insects are related to the start and end of the dry season in BCI. In this respect, our results are only partly congruous with Wolda's (1989) hypothesis because the last month of the dry season, April, showed the highest abundance of Ephuta on BCI. No similar peak, however, was found at the beginning of the dry season. Studies with other mutillid genera and in other habitats would be useful for further comparing these hypotheses. Thereby, our data shows that even though the sampling of Pompilidae and Ephuta on BCI was not conducted throughout the same period, their seasonal abundance appears to be synchronous which further reinforces their close host/parasite ecological relationship. Additionally, we have found that abundance for both groups seems to vary according with the average monthly temperature which in turn is a likely result of average monthly rainfall.

Ethical statement: authors declare that they all agree with this publication and made significant contributions; that there is no conflict of interest of any kind; and that we followed all pertinent ethical and legal procedures and requirements. All financial sources are fully and clearly stated in the acknowledgements section. A signed document has been filed in the journal archives.

\section{ACKNOWLEDGMENTS}

We thank Dumas Gálvez and the Central American Master's Program in Entomology at the University of Panama for the comments that helped improve this manuscript. The longterm malaise trap sampling on BCI was instituted by John Pickering (University of Georgia, USA) and was supported by funding from the "Environmental Sciences Program" of the Smithsonian Institution.

\section{RESUMEN}

\begin{abstract}
Abundancia estacional y anual de la avispa Ephuta (Hymenoptera: Mutillidae) en Panamá. Introducción: Ephuta es un género de avispas mutílidas ampliamente distribuido en el Nuevo Mundo y cuya ecología es poco conocida. Objetivo: El objetivo de este trabajo fue determinar cómo varía la abundancia de especies de Ephuta anualmente y estacionalmente debido a las condiciones climáticas y sus hospederos. Métodos: Se examinaron especímenes de Ephuta tomados de muestras semanales (2001-2006) de diez trampas Malaise, ubicadas en el "bosque viejo" de Isla Barro Colorado. La abundancia mensual de cada especie de Ephuta se comparó con el promedio mensual de la humedad, la radiación solar, la temperatura y las precipitaciones. Resultados: Se identificaron nueve especies y diez morfoespecies. La mayoría de los especímenes fueron recolectados de marzo a junio. La mayor abundancia mensual promedio se dio en abril. De las cuatro variables abióticas medidas, solo la temperatura mensual promedio se correlacionó con la abundancia de Ephuta. Los meses con el mayor número de especímenes de Ephuta se correlacionan con la sospechosa abundancia del huésped, como lo indica la abundancia mensual de Pompilidae (Hymenoptera) capturada durante el 2007. Conclusiones: Ephuta muestra una fuerte variación estacional en la abundancia, con picos durante el final de la estación seca y el comienzo de la temporada de lluvias. Esta se correlaciona ampliamente con la temperatura y la abundancia de sus huéspedes pompílidos.
\end{abstract}

Palabras clave: Mutillinae, Pompilidae, ecología, Isla Barro Colorado, neotrópico.

\section{REFERENCES}

Aranda, R., \& Graciolli, G. (2016). Environmental Heterogeneity in Parasitoid-Host Interaction for Mutillidae (Hymenoptera: Apocrita). Environmental Entomology, 45(5), 1107-1114. 
Brothers, D.J., \& Lelej, A.S. (2017). Phylogeny and higher classification of Mutillidae (Hymenoptera) based on morphological reanalyses. Journal of Hymenoptera Research, 60, 1-97.

Cambra, R.A., Tunes Buschini, M.L., Quintero, D., Brozoski, F., \& Rudiak Lustosa, P. (2017). Ephuta icema Casal, 1969 and its host Auplopus subaurarius Dreisbach, 1963 (Hymenoptera: Mutillidae, Pompilidae) from Brazil. Zootaxa, 4272(2), 285-290.

Cambra, R.A., Quintero, D., Waldren, G.C., Bartholomay, P.R., \& Williams, K.A. (2018). Taxonomic revision of the genus Timulla Ashmead, 1899 of Panama (Hymenoptera: Mutillidae). Tecnociencia, 20(2), 23-57.

Cambra, R.A., Williams, K.A., Quintero, D., Windsor, D.M., Pickering, J., \& Saavedra, D. (2018a). Dasymutilla Ashmead (Hymenoptera, Mutillidae) in Panama: new species, sex associations and seasonal flight activity. Insecta Mundi, 0608, 1-17.

Corro, P. (2014). Dinámica poblacional de avispas cazadoras de arañas (Hymenoptera: Pompilidae) en la Isla Barro Colorado, Panamá, República de Panamá (Unpublished master's thesis). Universidad de Panamá, Panama City, Republic of Panama.

Deyrup, M., \& Manley, D.G. (1990). Seasonal flight activity of male velvet ants (Hymenoptera: Mutillidae) in South Florida. Entomological News, 101(2), 99-108.

Kovach, W.L. (2011). Oriana: Circular Statistics for Windows (version 4.0). Pentraeth, Kovach Computer
Services. United Kingdom. Retrieved from https:// www.kovcomp.co.uk

Pagliano, G., Brothers, D.J., Cambra, R.A., Lelej, A.S., Lo Cascio, P., Matteini Palmerini, M.,... Romano, M. (2020). Checklist of names in Mutillidae (Hymenoptera), with illustrations of selected species. Bollettino del Museo Regionale di Scienze Naturali di Torino, 36(1-2), 5-427.

Quintero, D., \& Cambra, R.A. (1996). Contribución a la sistemática de las Mutílidas (Hymenoptera) del Perú, en especial las de la Estación Biológica BIOLAT, Río Manu, Pakitza. En D.E. Wilson \& A. Sandoval (Eds.), Manu: The Biodiversity of Southeastern Peru (pp. 327-357). Washington D.C., USA: Smithsonian Institution Press.

R Core Team. (2015). R: A language and environment for statistical computing. R Foundation for Statistical Computing. Vienna, Austria. Retrieved from http,// www.R-project.org

Townes, H. A. (1972). A light-weight Malaise trap. Entomological News, 83, 239-247.

Windsor, D.M. (1990). Climate and moisture variability in a tropical forest: Long-term records from Barro Colorado Island, Panama. Smithsonian Contributions to the Earth Sciences, 29, 1-149.

Wolda, H. (1988). Insect seasonality: why? Annual Review of Ecology and Systematics, 19, 1-18.

Wolda, H. (1989). Seasonal cues in tropical organisms: Rainfall? Not necessarily! Oecologia, 80, 437-442. 